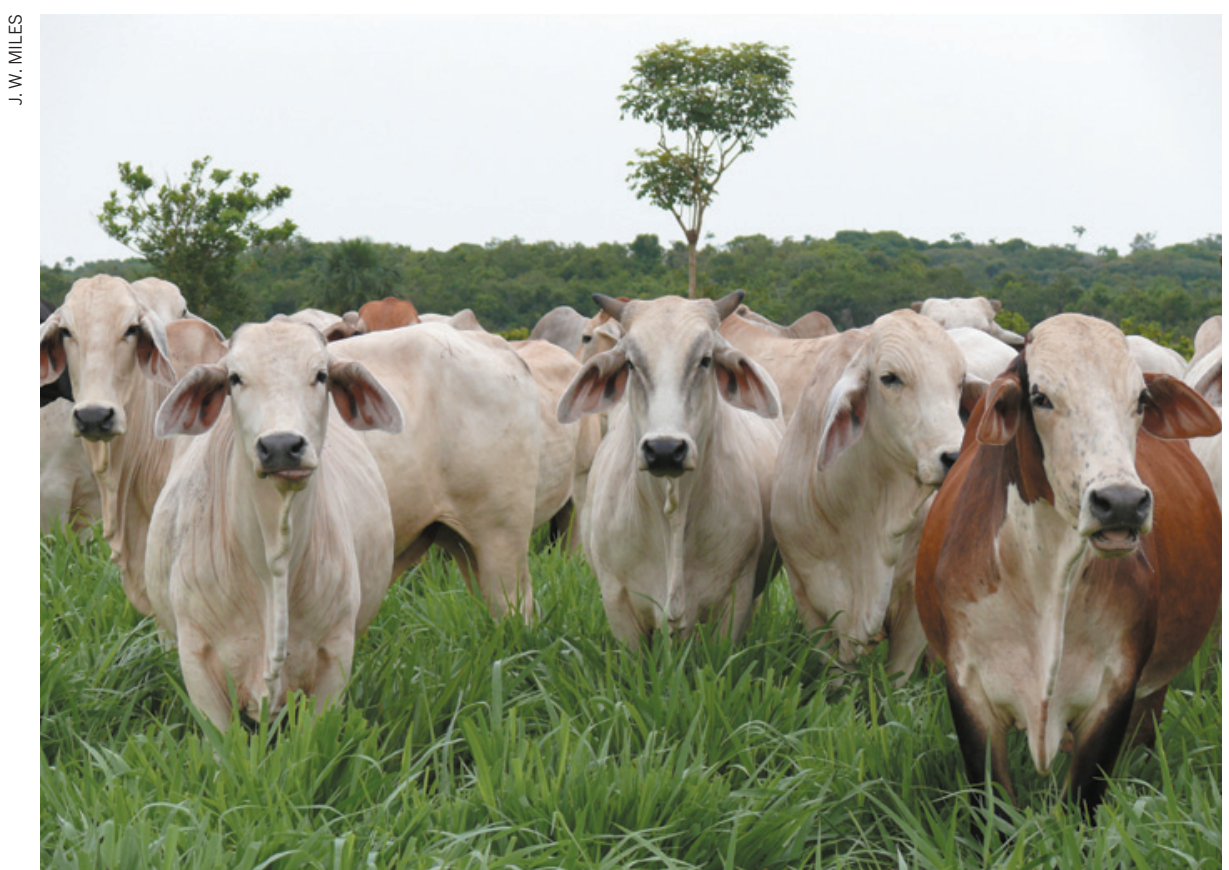

Brachiaria grasses, used as cattle pasture, have been bred to reduce nitrogen emissions caused by microbes.

\title{
AGRICULTURE
}

\section{Grass gets greener}

\section{Plant secretion curbs greenhouse-gas emissions from soil.}

\section{BY NICOLA JONES}

I ndustrial power plants take most of the flack for climate change. But nature's plants are not blameless: agricultural land is responsible for about 14\% of the world's greenhouse-gas emissions, slightly more than the global contribution from planes, trains and automobiles. So researchers have tried to 'green' up agriculture by breeding plants that cut the emissions associated with wasted fertilizer.

On 13 September, researchers announced that they have bred a tropical pasture grass that can significantly suppress greenhouse-gas emissions. The team, from the International Center for Tropical Agriculture (CIAT) in Cali, Colombia, is working with Dow AgroSciences, based in Indianapolis, Indiana, to get seeds onto the market in the next $3-5$ years.

Agriculture's climate problem is a nitrogenfertilizer problem. Fertilizer contains ammonium $\left(\mathrm{NH}_{4}^{+}\right)$; when it is first laid down, this positively charged ion stays put in the soil, sticking to negatively charged clay particles. But then nitrifying soil bacteria go to work, wreaking environmental havoc. They convert ammonium to nitrate $\left(\mathrm{NO}_{3}{ }^{-}\right)$, which washes into ponds and causes ecologically harmful algae blooms. Nitrate can also be converted to nitrous oxide $\left(\mathrm{N}_{2} \mathrm{O}\right)$ gas, which warms the planet 300 times more powerfully than carbon is adapted to low-nitrogen South American savannahs. After years of hunting, they identified a nitrification inhibitor secreted by the grass's roots. Called brachialactone, it reduces nitrous oxide emissions by blocking enzymatic pathways in nitrifying bacteria. That leaves more nitrogen available to help the plant to build tissues.

The team found similar activity in a few other plants, including sorghum, but Brachiaria grasses were best. The researchers have spent more than 8 years breeding the plants to maximize this ability. Peters says that they have doubled the release of nitrification inhibitors, and are now checking that this has not decreased the overall productivity of the grass. As a sidebenefit, the team reported this week at the $22 \mathrm{nd}$ International Grasslands Congress in Sydney, Australia, brachialactone seems to persist in the soil: maize (corn) grown in pastures that previously hosted Brachiaria produces nearly four times as much grain with low levels of fertilizer as maize grown in previously cropped land.

"The idea has legs," says Peter Grace, a soil scientist at the Queensland University of Technology in Brisbane, Australia, and coordinator of Australia's National Agricultural Nitrous Oxide Research Programme.

\section{CROP CHALLENGE}

Attacking the problem in grasslands is important: $85 \%$ of Earth's agricultural land is used for livestock forage. But crops, which are more heavily fertilized than grasslands, are much worse climate offenders. To tackle that problem, CIAT geneticists are trying to isolate the brachialactone genes, to introduce them into crops such as wheat or rice. Plants could then produce their own inhibitors when they sense high concentrations of ammonium in the soil.

Help might also come from genes that encourage faster uptake of nitrogen. Arcadia Biosciences, based in Davis, California, has taken a gene for an enzyme called alanine aminotransferase from barley and incorporated it into other crops to encourage them to absorb nitrogen before microbes do. On 10 September, Arcadia announced that in trials by CIAT, African rice with this gene produced the same yield as controls, using only half the fertilizer. Arcadia expects commercial partners to bring seeds to market by 2017, and in December 2012, the United Nations Clean Development Mechanism approved a plan for farmers to earn sellable 'emissions reduction' credits by using the company's technology.

Grace points out that there are also effective low-tech approaches to reducing emissions. Farmers can refine how and when they apply fertilizers; for example, they can avoid lots of nitrogen being washed away when snow melts Tilling less and periodically planting crop fields with nitrogen-fixing legumes can also help to keep nitrogen in the soil. "The easiest way is to simply restrict the amount of fertilizer applied," says Grace. 